\title{
Measurement method to test the strength of peg and tie joints against tensile strength and press on simple bamboo structure
}

\author{
A.N.S. Gunawan \& S. Mohamad \\ Universiti Sains Malaysia, Penang, Malaysia
}

\begin{abstract}
The search for an effective connection tool for assembling bamboo is mostly done by researchers and architects. Either conventional or trying to change the bamboo into the form of other materials. The search for a new connection tool wasn't followed by test regarding the strength of the bamboo strings against compressive and tensile forces. The goal of testing the strength of the tool connected and bamboo aims to see the pattern of damage to the bamboo that will occur due to the use of the tool connected. Testing is done by creating a model of the test object circuit structure simply with the use of the tool Universal Testing Manual (UTM) Ibertest type of Eurotest. The results of the test show a lot more damage caused by power urges the bamboo on the hollow part of the bamboo as the space/layout of the connection pegs.
\end{abstract}

Keywords: connection tool, bamboo, tensile force, compressive force, the strength of the urges

\section{INTRODUCTION}

Many researchers, practitioners, and architects try to renew stitch bamboo as a building structure. The update is an effort of invention and a creation tool to connect new use in stringing the bamboo for the structure of the building. Morisco (1998) and Pathurrahman (1998) conducted a study increase in the strength of the connection on the bamboo to make the connection fill the bamboo with the aim of making the bamboo that will be spliced into a composite, similar to research done by Hogan and Archer 2010) by filling in the mortar and gave the steel reinforcement on the part of the bamboo that will be spliced. Nugraha (2012) conducted a similar study but using resin as a material filler and did variation testing with a wide variety of corner styles $\left(0^{\circ}, 45^{\circ}, 60^{\circ}\right)$.

Analysis of the resistance of the lateral joints of wood and mortar fillers, known as Morisco Mardjono joints, was carried out by applying EYM (European Yield Theory). This analysis aims to formulate the strength of the Morisco Mardjono lateral joint system which is influenced by the geometry data connection, the bending moments of the bolts and bamboo fulcrums, and the material fulcrum points (Awaludin 2012). However, testing the re-facing tool to connect the new and the old did not do much. The physical condition of the bamboo, which is hollow, is composed of parallel fiber; the nature of the expansion and shrinkage create a problem for the construction of bamboo as a structural element of the building.

There are three common means of connecting: tie, stake, and substitution. It is necessary to test the effectiveness of the power of each system based on materials used. In the coupling structure of the building, the structural elements have to meet the requirements of the strength against a tensile force and compressive force, or both because part of the structure is subjected to traction, pressure, or both (Salvadori 1990). It turns out it is influenced also by how to compose the elements of the structure of bamboo which will have an impact on the stability of the building reduction because of the connection factors between bamboo stem by resistance elements (Sassu et al. 2012). A common problem is to equate how to connect with the use of a connection system which isn't an appropriate function of the mechanic is received on a connection of the bamboo. 
To recognize further related to the behavior of the connection due to the use of the tools connect a special method for testing is needed. Scientific writing describes one of the techniques of measurements of the strength of bamboo and provides a means of connecting that is used as well as the impact of damage to the mechanical well on the bamboo and on the tools used.

\section{RESEARCH METHODS}

\subsection{Stimuli}

This research used the quantitative method, utilizing a comparative study and an experimental study. Before doing the testing, exploration studies were carried out in the literature related to the principles of work and distribution of the load and the force on a series of bamboo construction and experiment in the circuit of the simple construction of bamboo, such as the use of test equipment compressive and tensile strength.

The results of the observation and search of a comparative study found how there are two kinds of connection base. The first is the connection with the belt (rope) and pegs.

\subsection{Subject}

This research was done in an effort to discover how to make a simple circuit according to the principles of the compressive force, The tensile force received and borned, will be distributed on each rod element in the series of truss system/truss system (Salvadori 1981 in Gunawan et al. 2013) trunks interconnected with joints on the ends of the rod and distributes the load on the dots connect the gusset on the truss system/truss system by using a means of connecting a rope or a means of connecting pegs.

\subsection{Research procedures}

First, make a model of the test object with a variety of connection devices of different types. The model in the form of an equilateral triangle with length 12 is $2 \times 11$. Then the value of $h$ can be calculated by calculating the Pythagorean formula, as follows:

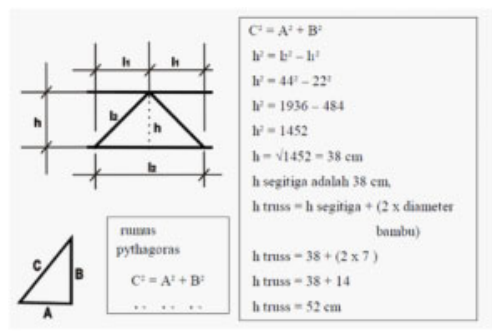

Figure 1. The formula of calculation of the dimensions of the model will be made. (Source: Ahmad Nur Sheha Gunawan, 2013)

The second stage is the manufacture of the test object.

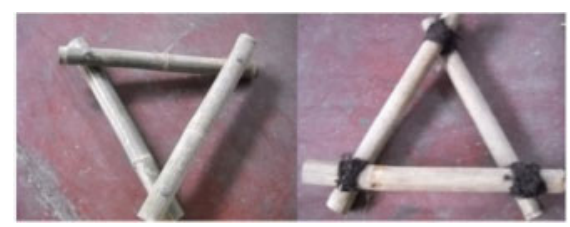

Figure 2. The test specimen to a compressive force and drag created in the form of simple construction. (Source: Ahmad Nur Sheha Gunawan, 2013) 
The third stage is to test the strength of the test specimen laboratory test by using the tool Univeral Testing Manual (UTM) Ibertest type Eurotest. Universal Testing Manually is a machine used to test the tensile stress and compressive strength at material or materials with a variety of standards and compression on materials, components, and structures. In the case of this test, the bamboo material strung together in a series of structurally simple with a means of varying connection. Machine Universal Testing Machine can do tensile testing with many standards and compression tests on materials, components, and structures.

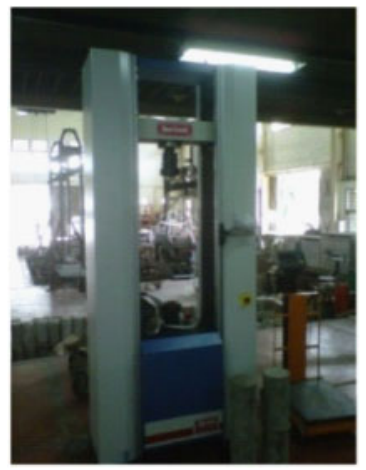

Figure 3. Manual testing images laying objects on measuring University (UTM)Eurotest type. (Source: Ahmad Nur Sheha Gunawan 2013)

The fourth stage is the laying of the test object on the testing tool.

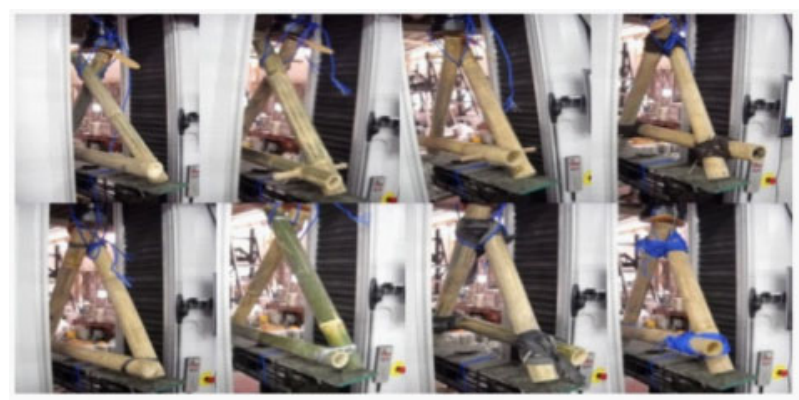

Figure 4. Manual testing images laying objects on measuring University (UTM) Eurotest type. (Source: Ahmad Nur Sheha Gunawan 2013)

After the model test objects are created and ready to test, the model test object is brought into the laboratory for testing the test tap and drag using the tool Universal Testing Manual (UTM) Ibertest type Eurotest with a capacity of the capacity test load up to 20 tons. The purpose of this test is to see the performance of the connection at the point of connection with the given treatment of compressive load and tensile load. The test object is laid on the tool UTM Ibertest type Eurotest which then gives the load to fit the performance you want to see, e.g., compressive or tensile strength. A large burden of work is set by the load control and the data recorded digitally in the computer instruments testing tool. The control of the load on the tool is set digitally, so that when the test object is damaged, then shifted, and the shape of the tool is deformed, the test will stop and generate measurement data in the form of data maximum load, maximum strength, and displacement/shift of position. 


\section{RESULTS AND DISCUSSION}

Testing is done by creating a model of the test object $1: 1$. The specimen was tested with the machine tool UTM Ibertest type Eurotest.

The model was made for testing the press. The experimental data of test force laboratory structure and material civil engineering Institute of Technology Bandung (ITB) in the form of numeric data/numbers and the image data in the form of recording the process and results of testing.

By using Microsoft Excel, the measurement results data are displayed in the form of numerical data and graphics which are then interpreted as a description of the results of the measurement model testing. Data measurement results in the form: maximum load, maximum power, and a shift/position of a series of the truss. After the trial was carried out, the following data were obtained.

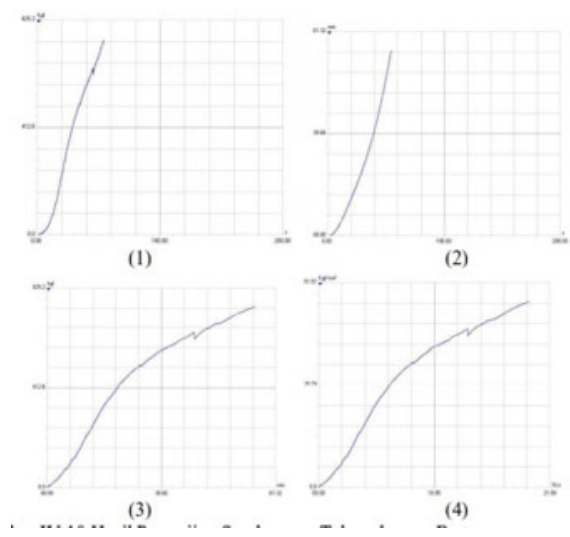

Figure 5. The results of testing the connection press: (1) compressive weight force (kgf) vs. time (s); (2) displacement distance ( $\mathrm{mm}$ ) against time (s); (3) compressive weight force (kgf) against sliding (mm); and (4) the compressive weight of the style/field press against the percentage of strong heavy press style $\%$ Lo.

Press testing on the test object by using a means of connecting bolts shows that the load maximum pressure capable of being held by $750.2 \mathrm{~kg}$, while the maximum power capable of being held by of $46.9 \mathrm{~kg} / \mathrm{cm}^{2}$, the displacement distance due to the drag maximum is $55,745 \mathrm{~mm}$.

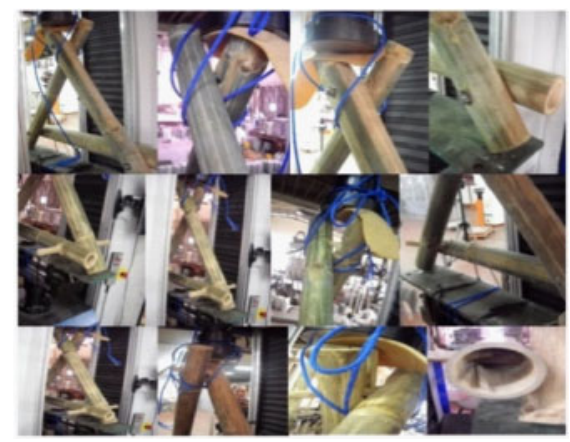

Figure 6. The damage on the model test press with machine UTM. (Source Ahamd Nur Sheha Gunawan 2013)

From the test, it is known that the damage to bamboo is caused more by the force of the bamboo against the hollow part of the bamboo as a place for connection pegs. The stiffness of the post (related to the type of material) also plays a role in the breakage. Damage to bamboo with wooden pegs is different from damage caused by the stiffness of metal pegs. The amount of tensile strength 
and compressive strength acting on a series of simple specimens is not the main cause of damage to the joined bamboo stems. Holes that are too big or too small also have a role in the damage to the bamboo strung. Weakening due to improper perforation causes the friction force of the pegs against the bamboo (in the holes) because it is loose so that the force acting on the pegs to bamboo causes the bamboo to break, especially in joints with hard-made pegs such as metal. Whereas on soft pegs such as wood and bamboo, more damage occurs to the pegs.

So, it can be said that the weakening of the joint is also influenced by the size and position of the hole, the type of peg material. In structural elements that are dominant, the tensile force tends to damage because the bamboo which functions as a tensile rod will result in a reduction in the area of the tensile rod which affects the tensile strength where the distribution of the tensile load is not evenly distributed but there is a right stress concentration on the edge of the hole of the one-way connection tool. tensile force. This can be explained through the theory of elasticity (Suryoatmojo, 1997 in Gunawan 2013). An element that has a hole in the middle is loaded with a centric dance load will cause an uneven load distribution (stress concentration occurs), right on the edge of the large hole in the direction of tensile stress. An element that experiences a compressive force will experience a bending force up to the maximum yield stress and buckling occurs because of the instability of the compressive element.

In the model with a tie object, bamboo does not suffer significant damage, but the structural structure of bamboo changes shape. This is due to the elastic-plastic binding material of bamboo.

\section{CONCLUSION}

The test results and exposure above concluded that the damage to the structure of bamboo is not only determined by the size of the style, but also the related issue of the type of bamboo (the physical properties of bamboo are arranged by the parallel fiber), layout connection, large hole connection, the connection type, and the material of the tool connect.

It can be an input related to the creation of a means of connecting the new to further consider physical form, the nature of the character of bamboo, and the laying of the tool connected. In particular, a means of connecting based stake.

The idea that appears related to new connection tool is how to create a means of connecting bamboo that is strong without damaging it, related to the bamboo physical form with fibers shaped in parallel direction.

\section{REFERENCES}

Barry, R. 1984. The Construction of Buildings. 3rd edition Vol. 3: Single Storey Frames, Shells and Lightweight Coverings. London: Granada

Frick, Heinz. 2004. Ilmu Konstruksi Bangunan Bambu Pengantar Konstruksi Bambu. Yogyakarta: Penerbit Kanisius.

Frick, Heinz. 1997. Pola Struktural dan Teknik Bangunan di Indonesia. Yogyakarta: Penerbit Kanisius.

Frick, Heinz. and Purwanto, L.M.F. 1998. Sistem Bentuk Struktur Bangunan, Dasar-Dasar Konstruksi Dalam Arsitektur. Yogyakarta: Penerbit Kanisius.

Frick, Heinz., L and Setiawan, Pujo. 2001. Ilmu Konstruksi Struktur Bangunan, Cara membangun Kerangka Gedung Ilmu Konstruksi Bangunan 1. Yogyakarta: Penerbit Kanisius.

Hadjib, N. and Karnasudirdja, S. 1986. Sifat fisik dan mekanis bambu andong (Gigantochloa verticillata Mur.), betung (Dendrocalamus asper Back) dan ater (Gigantochloa ater Kurz). Laporan Intern Pusat Penelitian dan Pengembangan Hasil Hutan dan Sosial Ekonomi Kehutanan Bogor.

Jassen, J. 2011. Draft ISO: N315. Laboratory Manual on Testing Methods for Determination of Physical and Mechanical Properties of Bamboo. Draft ISO/TC 165/WG9, Determination of Physical and Mechanical Properties of Bamboo .

Morisco. 1999. Rekayasa Bambu. Yogyakarta: Nafiri Offset.

Schodek, D. L. 1998. Dalam D. L. Schodek, Struktur. Bandung: PT. Refika Aditama. 